\title{
THE EFFECT OF APPLICATION OF RICE DISHWATER AND MANURE AS ORGANIC FERTILIZER TO THE GROWTH OF MUSTARD (Brassica Juncea L.)
}

\author{
Amalia Noviyanty $^{\text {I) }}$ Chitra Anggriani Salingkat ${ }^{1)}$ \\ ${ }^{1)}$ Study Program of Agrotechnology Faculty of Agriculture, Tadulako University, Palu
}

\begin{abstract}
One of the recommended concepts of organic agriculture is the use of organic fertilizers and minimizing the use of inorganic fertilizers in farming activities or crop cultivation. Manure is one of the organic fertilizers that are often used as fertilizer, one of which is goat manure. In addition, there are several types of household waste that can be used as liquid organic fertilizers such as the waste rice washing water that can be applied to plants. The research objective were to determine the effect of giving rice washing water waste and manure to the growth and yield of mustard plants. This research was conducted from February to April 2017. This study used a randomized block design with two factors consisting of 16 treatments and repeated three times. The first factor isto control rice washing waterwith a concentration of 10, 20 and $30 \mathrm{ml} /$ liter of water and the second factor is manure consisting of control, manure 5, 10 and 15 grams. This study uses quantitative data analysis techniques. Analysis of quantitative descriptive data used is plant height and number of leaves.Observation results of plant height showed that the highest average of plant height was experienced by $20 \mathrm{ml} / \mathrm{liter}$ rice washing water and 15 goat manure treatment. Likewise, the average number of leaves of mustard plants was not significantly different from the treatment of rice washing water, but the number of leaves in mustard plants was not significant. The results showed there were no significant interactions between the concentration of rice washing water and manure doses on growth and yield of mustard greens The rice washing water did not have a significant effect on plant height and number of leaves. The difference in the results of this study was thought to be caused by differences in the types of rice used.
\end{abstract}

Keywords: Manure, Mustard Plants, Waste rice washing water.

\section{PRELIMINARY}

Mustard greens (Brassica juncea L) is one of the horticultural crops of vegetables which are used as young leaves, as vegetable food and have various benefits and uses. In everyday people's lives, mustard greens besides being used as food and vegetable ingredients can also be used for treatment (Cahyono, 2003). Mustard greens contain vitamins such as protein, calcium, phosphorus, vitamin A, vitamin B, vitamin $C$. In addition, this plant is rich in fiber which is useful for digestive health (Haryanto, 2007).

In its processing, rice undergoes a washing step before cooking. In this step, it is usually washed or rinsed 3 times in order to clean the rice from dirt. Rice washing water or often referred to as Leri (Javanese) is milky white, showing eroded protein and vitamin B1 which is abundant in rice. Admittedly, Leri will be rich of these contents. Vitamin B1 is a group of B vitamins, which have a role in plant metabolism in terms of converting carbohydrates into energy to move activity in plants (Wulandari et al., 2011). In addition, rice washing water has an effect on increasing the number of leaves and plant height. One of the contents of rice washing water is phosphorus which is a macronutrient that is needed by plants (Yulianingsih, 2017). Furthermore (Handiyanto et al., 2013) stated that rice washing water waste can increase the growth of white oyster mushroom mycelia on pure culture. 
Subandi, et al. (2015) stated that horticulture plants, especially leaf vegetables, play an important role because they contain more vitamins than other types of vegetables.

Sustainable cultivation of mustard is needed to obtain mustard products desired by consumers, which are of good quality, healthy and safe for consumption. Sustainable cultivation is reducing or minimizing the use of inorganic fertilizers and increasing the use of organic fertilizers.

In organic farming activities, most farmers use manure. One of the animals that are quite potentials as a source of organic fertilizer is goats. Goat manure contains $2.45 \% \mathrm{~N}$; P $1.13 \%$; and K 3.5\%. Elements of nitrogen, phosphorus, and potassium are the main elements needed by plants in large quantities (Sajimin, et al., 2005).

The purpose of this study was to determine the effect of giving rice washing wastewater and manure to the growth of mustard plants.

The benefit of this research is to be able to get information about the utilization of household waste that is used as an organic fertilizer more effectively and add insight into the content of rice washing water in plants.

\section{RESEARCH METHODS}

This research was carried out in Mantikulore Village, Palu City. It began in February to April 2017.

The materials used in this study were rice washing wastewater from the first rinsing house waste, $1 / 2 \mathrm{~kg}$ brown sugar, 2 liters of coconut water, EM4, soil, goat manure obtained at the Green House of the Faculty of Agriculture, University of Tadulako Palu, and mustard seed red arrow brand.

The tools used in this study are small shovels, ruler, books, label paper, small plastic hoses, polybags, pens, buckets, spray, and cameras.

Experiment Method. In this treatment used a factorial randomized block design method with 48 units of the experiment, 16 treatments repeated 3 times. The factors studied included rice washing water and manure doses

1. The factor of rice washing water (A) consisting of 4 factors, namely:

A0: control

A1: Rice washing water with a concentration of $10 \mathrm{ml} / \mathrm{liter}$ of water

A2: Rice washing water with a concentration of $20 \mathrm{ml} /$ liter of water

A3: Rice washing water with a concentration of $30 \mathrm{ml} /$ liter of water

2. Manure factor $(\mathrm{K})$ which consists of 4 factors, namely:

K0: control

$\mathrm{K} 1: 5$ gram of manure

$\mathrm{K} 2$ : 10 gram of manure

K3: 15 grams of manure

\section{Implementation of Research}

Nursery. Sand and manure are sieved first, then the sand sieve and manure are mixed with a ratio of $1: 1$. The mixture is put into the tray before the green mustard seeds are spread or planted, the planting media is doused with water until the soil is moist. Green mustard seeds are sown for 3-4 weeks then the seeds can be transferred to a polybag.

Preparation. Before planting, the provided medium consisted of soil, rice husk, and manure is mixed evenly with a ratio of $1: 1$ : 1. Furthermore, this medium is inserted into the polybag and arranged at the specified place based on the method of randomization used.

Planting. After the plants are 3-4 weeks old with the number of leaves 3-4 strands, these plants will be moved to each polybag.

1. The application of household organic fertilizer for organic fertilizer is carried out every week starting from the time the plants are moved from the nursery to the polybag according to the dosage of each treatment.

2. Maintenance. Maintenance carried out includes: 
a. stitching: If there are dead plants, the embedding is carried out no later than one week after planting.

b. Watering: Watering is conducted in the morning and evening. When the weather is not that sunny, it will be carried out once a day.

c. Weeding: Weeding is every time there are weeds or grasses that grow around the plants.

d. Fertilization: After 1 week of planting, basic fertilization is carried out with the same dose for each treatment. Followed by supplementary fertilization every week after basic fertilization is carried out, with each treatment a different dose until the fifth week.
Making Rice POC. The research was conducted by preparing tools and materials for the manufacture of liquid organic fertilizer (POC). POC is conducted by preparing 2 liters of rice water, then the prepared rice water is put into a bucket that has been provided and then mixed with coconut water and brown sugar which has been mashed after all the liquid organic fertilizer material has been mixed in one container then the bucket is closed tightly, then fermented in a plastic bucket that has been prepared for two weeks (Hairudin, 2015). Analysis of quantitative data testing was conducted by calculating the average growth of mustard plants, namely plant height and the number of leaves.

Table 1. Mustard Height Average (cm) in Rice Washing Water and Manure Treatment.

\begin{tabular}{llllll}
\hline & \multicolumn{5}{c}{ Week... } \\
\cline { 2 - 6 } Treatment & \multicolumn{7}{c}{ I } & & II & III & IV & V \\
\cline { 2 - 6 } & & & & & \\
\hline A0K0 & 5.33 & 6.83 & 7.00 & 10.67 & 14.50 \\
A0K1 & 6.00 & 7.17 & 8.83 & 13.07 & 16.50 \\
A0K2 & 6.33 & 8.50 & 6.83 & 11.80 & 16.00 \\
A0K3 & 6.00 & 7.67 & 10.03 & 14.50 & 18.17 \\
A1K0 & 6.17 & 8.17 & 9.67 & 14.00 & 16.83 \\
A1K1 & 5.50 & 6.83 & 6.50 & 12.07 & 17.33 \\
A1K2 & 5.17 & 8.17 & 9.67 & 10.50 & 15.33 \\
A1K3 & 6.17 & 8.00 & 10.17 & 11.20 & 20.87 \\
A2K0 & 4.50 & 6.50 & 10.17 & 8.67 & 15.87 \\
A2K1 & 5.50 & 8.50 & 11.17 & 9.87 & 15.60 \\
A2K2 & 4.67 & 7.00 & 10.17 & 10.00 & 21.83 \\
A2K3 & 5.83 & 8.50 & 10.67 & 10.00 & 23.17 \\
A3K0 & 6.43 & 8.67 & 10.50 & 12.67 & 17.00 \\
A3K1 & 5.00 & 7.17 & 8.17 & 10.33 & 19.67 \\
A3K2 & 6.00 & 8.17 & 10.33 & 12.33 & 18.50 \\
A3K3 & 6.00 & 8.00 & 8.33 & 10.00 & 16.57 \\
\hline
\end{tabular}

Description: A0K0: control, A0K1: control and manure $5 \mathrm{gr}, \mathrm{A} 0 \mathrm{~K} 2$ : control and manure $10 \mathrm{gr}$, A0K3: control and manure $15 \mathrm{gr}$, A1K0: rice washing water $10 \mathrm{ml} /$ liter water and control, A1K1: washing water $10 \mathrm{ml} /$ liter of water and 5 gr of manure, A1K2: rice washing water $10 \mathrm{ml} /$ liter of water and $10 \mathrm{gr}$ of manure, A1K3: rice washing water $10 \mathrm{ml} /$ liter of water and $15 \mathrm{gr}$ of manure, A2K0: Rice washing water $20 \mathrm{ml} /$ liter of water and control, A2K1: Rice washing water $20 \mathrm{ml} /$ liter of water and manure $5 \mathrm{gr}$, A2K2: Rice washing water $20 \mathrm{ml} /$ liter of water and manure $10 \mathrm{gr}, \mathrm{A} 2 \mathrm{~K} 3$ : Rice washing water $20 \mathrm{ml} /$ liter of water and manure $15 \mathrm{gr}$, A3K0: Rice washing water 30 $\mathrm{ml} /$ liter of water and control, A3K1: Rice washing water $30 \mathrm{ml} /$ liter of water and manure $5 \mathrm{gr}, \mathrm{A} 3 \mathrm{~K} 2$ Rice washing water $30 \mathrm{ml} /$ liter of water and manure $10 \mathrm{gr}$, A3K3 : Rice washing water $30 \mathrm{ml} /$ liter of water and $15 \mathrm{gr}$ of manure. 
Parameters of Research. The research parameters observed were as follows:

1. Mustard plant height $(\mathrm{cm})$ is measured from the surface of the land to the highest leaf edge. Measurements are made when plants are 1,2, 3, 4 and 5 MST.

2. The number of leaves (strands) are calculated on leaves that have opened or are perfectly formed. Measurements were taken when the plants were $1,2,3$, 4 and 5 MST.

\section{RESULTS AND DISCUSSION}

Plant Height. The plant height continues to increase until the end of the observation period based on the plant age increase and the concentration of rice washing water and manure provided. The observation results are shown in Table 1.

The increasing of plant height is an indicator of plant growth and development that determines the productivity of a plant.A plant will grow when the necessary elements are sufficiently available in a form properly to absorb (Kii et al., 2018).

The increase in plant height occurs because cell division and an increase of cell numbers require energy in form of ATP (Aisyah, et al., 2018).

The observation results showed that the highest average of plant height witnessed by rice washing water $20 \mathrm{ml} /$ liter and manure 15-gram treatment with the value $23.17 \mathrm{~cm}$. In contrast, rice washing water $20 \mathrm{ml} /$ liter and without manure treatment is was the lowest average with a value of 4.50 $\mathrm{cm}$. The results revealed that there were no significant interactions between the doses of rice washing water and manure doses on all growth variables and observed mustard yields.

This is due to the provision of rice washing water that is not maximal or the lack of a dose given to mustard plants, with the highest dose being $30 \mathrm{ml} /$ liter. Rice washing water contains nutrients $\mathrm{N}, \mathrm{P}$ and ZPT (Substance Regulating Growth). If the dose given is less than what is needed by the plant, the supply of nutrients to the plant decreases so that it will affect the growth and production of plants.

This is in accordance with Wulandari's statement, (2011) suggesting that the provision of rice washing water has no significant effect on the growth of lettuce canopies such as plant height, stem diameter, leaf greenness, leaf area, fresh weight, and canopy dry weight and fresh and heavyweight dried plants.

The result showed that there is no significant effect of adding rice washing water and manure with the various concentration on mustard plant growth when viewed from the variance. Based on observation, it can be seen that $20 \mathrm{ml} /$ liter rice washing water and $15 \mathrm{~g}$ manure treatment effect experienced the highest number of plant height. It is suspected that this treatment contains by plenty of Pseudomonas fluorescence. These microbesplay role in controlling pathogens that cause rust and triggering the plant growth so that the plant development can be more effective (Hairudin, 2015).

These bacteria are able to adapt well to plant roots and can inhibit the growth and activity of the pathogen, or in other words, it can make plants more immune to the disease. In addition, they produce phytohormones. These hormones can stimulate growth, including lengthening and raising stem cells, inhibiting the process of leaf abortion, and also stimulating fruit formation. The increasing number of plant height at 15gram doses of manure treatment shows that the nutrients needed by plants mustard are available in a balanced state, so it can trigger the growth and optimum yields. Giving goat manure affects the leaf area and the height of mustard plants (Supardi, 2011). It is caused by goat manure has high nutrient content of potassium (K). This element play role in strengtheningthe stem and developing the root (Amitasari, 2016).

The result comparison between several treatments (K1 and K2) in control term was not significantly different. It is estimated that the nutrients had not 
sufficiently available for plants because the organic nutrient process requires considerable time and large amounts to be absorbed.

Rosmarkam et al. (2002) also revealed that rice washing water waste can fulfill plant nutrient needs, so that it can support plant metabolic processes and provide a good impact on plant growth. The difference in the results of this study is thought to be caused by differences in the types of rice used.

Furthermore, the other expected factors are the concentration of liquid organic fertilizers have not been absorbed optimally, so that they have less effect on the growth of mustard plants. The entry of a solution into cells is strongly influenced by the concentration of the solution, both inside and outside of cells, which is absorbed by plant cells by diffusion from low to high concentrations (high to low potential) (Vika et al, 2018).

The giving liquid organic fertilizer must notice to the concentration applied to the plant because excessive concentrations result in symptoms of wilting in plants (Suparhun et al., 2015).

Table 2. Average Number of Leaf (Strands) of Sawi Plants in Water Treatment for Rice and Cage Fertilizers.

\begin{tabular}{|c|c|c|c|c|c|}
\hline \multirow{2}{*}{ Treatment } & \multicolumn{5}{|c|}{ Week } \\
\hline & I & II & III & IV & V \\
\hline $\mathrm{A} 0 \mathrm{~K} 0$ & 2.67 & 4.67 & 4.00 & 5.33 & 6.00 \\
\hline $\mathrm{A} 0 \mathrm{~K} 1$ & 3.00 & 4.67 & 4.33 & 5.33 & 6.00 \\
\hline $\mathrm{A} 0 \mathrm{~K} 2$ & 3.00 & 4.33 & 4.00 & 4.67 & 6.00 \\
\hline A0K3 & 3.33 & 5.00 & 5.67 & 5.67 & 6.00 \\
\hline $\mathrm{A} 1 \mathrm{~K} 0$ & 3.00 & 4.67 & 5.33 & 5.00 & 7.00 \\
\hline A1K1 & 2.67 & 5.33 & 4.33 & 5.33 & 7.00 \\
\hline $\mathrm{A} 1 \mathrm{~K} 2$ & 3.00 & 5.00 & 5.00 & 5.33 & 7.33 \\
\hline A1K3 & 3.33 & 5.00 & 4.67 & 5.00 & 7.33 \\
\hline $\mathrm{A} 2 \mathrm{~K} 0$ & 3.33 & 4.67 & 5.00 & 6.00 & 7.00 \\
\hline $\mathrm{A} 2 \mathrm{~K} 1$ & 2.67 & 5.00 & 5.33 & 5.33 & 6.00 \\
\hline $\mathrm{A} 2 \mathrm{~K} 2$ & 2.67 & 5.00 & 6.00 & 5.00 & 7.00 \\
\hline $\mathrm{A} 2 \mathrm{~K} 3$ & 2.67 & 5.00 & 5.00 & 5.00 & 7.00 \\
\hline $\mathrm{A} 3 \mathrm{~K} 0$ & 3.00 & 4.33 & 5.00 & 5.67 & 7.33 \\
\hline A3K1 & 3.33 & 4.67 & 5.33 & 5.33 & 7.33 \\
\hline A $3 \mathrm{~K} 2$ & 3.00 & 4.67 & 4.67 & 6.00 & 7.33 \\
\hline $\mathrm{A} 3 \mathrm{~K} 3$ & 3.00 & 4.67 & 5.00 & 5.33 & 7.00 \\
\hline
\end{tabular}

Description: A0K0: control, A0K1: control and manure 5 gr, A0K2: control and manure $10 \mathrm{gr}$, A0K3: control and manure $15 \mathrm{gr}$, A1K0: rice washing water $10 \mathrm{ml} /$ liter water and control, A1K1: washing water $10 \mathrm{ml} /$ liter of water and 5 gr of manure, A1K2: rice washing water $10 \mathrm{ml} /$ liter of water and $10 \mathrm{gr}$ of manure, A1K3: rice washing water $10 \mathrm{ml} /$ liter of water and $15 \mathrm{gr}$ of manure, A2K0: Rice washing water $20 \mathrm{ml} /$ liter of water and control, A2K1: Rice washing water $20 \mathrm{ml} /$ liter of water and manure $5 \mathrm{gr}$, A2K2: Rice washing water $20 \mathrm{ml} /$ liter of water and manure $10 \mathrm{gr}, \mathrm{A} 2 \mathrm{~K} 3$ : Rice washing water $20 \mathrm{ml} /$ liter of water and manure $15 \mathrm{gr}$, A3K0: Rice washing water 30 $\mathrm{ml} /$ liter of water and control, A3K1: Rice washing water $30 \mathrm{ml} /$ liter of water and manure $5 \mathrm{gr}, \mathrm{A} 3 \mathrm{~K} 2$ Rice washing water $30 \mathrm{ml} /$ liter of water and manure $10 \mathrm{gr}$, A3K3 : Rice washing water $30 \mathrm{ml} /$ liter of water and 15 gr of manure. 
Number of Leaves (Strands). Additions to the number of leaves are related to the activity of meristematic cells in growth points, which occur due to apical meristem cell division in terminal buds and lateral keys that produce new cells and will grow leaves (Amrullah et al., 2013).

Growth is also supported by the availability of sufficient nutrients, among others, nitrogen, phosphorus and potassium (Amrullah et al., 2013). According to Sitompul and Guritno (1995), leaves function as organs for the photosynthesis process. Reducing the number of leaves causes a reduction in the rate of plant photosynthesis. In the process of photosynthesis, nutrients also play a role in plant metabolic activities.

The effect of various concentrations of rice washing water and goat manure on the number of mustard plant leaves at the age of 1, 2, 3, 4 and 5 MST is shown in Table 2. From the observations, the average number of leaves of mustard plants was not significantly different from the treatment of rice washing water, but the number of leaves in mustard plants is not significant. The average number of leaves of mustard plants at the fifth week is 7.33 of the most strands compared to other plants because the leaves are a place for plant photosynthesis aided by the addition of POC. It causes the number of leaves is more compared to other treatments, due to liquid organic fertilizer contains $80 \%$ vitamin B1, $70 \%$ vitamin B3, $90 \%$ vitamin B6, and nitrogen content which spurs the growth of the number of leaves.

During the rice washing process, the first washing water will usually be milky. This color indicates that the outer layer of rice is eroded. Although many nutrients have been lost, the very essential remnants nutrients still can be found in the epidermis. For instance, Phosphorus $(\mathrm{P})$ is one of the main elements needed by plants and is always present in plant compound fertilizers. This element helps plants to grow faster. Other nutrients are iron which is important for the formation of chlorophyll. In addition, the epidermis also contains vitamins, minerals, and high phytonutrients.
According to Lestari (2010), rice washing water still contains a lot of substances that can be used as plant fertilizers, instead of water media, and have a high carbohydrate content. Carbohydrates are a medium for the formation of Auxin and Gibberellin hormones, which are two types of compounds that are widely used in synthetic ZPT. Auxin hormone is useful for stimulating shoot growth and the emergence of new shoots, while Gibereline is useful for root growth stimulation.

Branch watered plants experience the slowest growth compared to others. This causes the growth of mustard leaves cannot be optimal. According to Sutanto (2002) that the benefits of organic fertilizer are preventing the environmental pollution caused by pesticides residue as well as other agricultural chemicals. Organic fertilizers have many great advantages such as improving soil structure, increasing fertility, maintaining and increasing the availability of nutrients and increasing microbial activity. According to Sutanto (2002), the metabolism process of the plant will be hampered if it cannot fulfill the nutrient elements needed. Consequently, it will affect plant growth and development. Therefore, even the organic matter has been used, it is necessary to add additional nutrients (through fertilization).

Rice washing water (Leri) is waste derived from the process of rice washing. This waste is generally thrown away, even though in fact it is rich in various organic compounds and minerals (Wardiah, 2014). Rice washing water contains vitamin B1 $0.043 \%$, phosphorus $16.306 \%$, nitrogen $0.015 \%$, potassium $0.02 \%$, Calcium $2.944 \%$, magnesium $14.252 \%$, sulfur $0.027 \%$ and iron $0.0427 \%$ (Wulandari, 2012). In preparation cooking process, the rice is washed. At washing process, it is generally washed or rinsed 3 times for ridding the dirt.The washing water (Leri) is milky, which means that protein and vitamin B1 contents are eroded. Therefore, the Leri contains lots of protein and vitamin B1. Vitamin B1 is a group of vitamin B, 
which converts carbohydrate into energy driving the plant's activity.

Goat manure contains $2.45 \% \mathrm{~N}$; P $1.13 \%$; and $\mathrm{K} 3.5 \%$. Nitrogen, phosphorus, and potassium are the main elements needed by plants in large quantities (Sajimin et al., 2005). This is in accordance with Ismaya et al (2014) stating that liquid organic fertilizer is a fertilizer with a maximum chemical content of $5 \%$. Hence, the $\mathrm{N}, \mathrm{P}$ and $\mathrm{K}$ content of liquid organic fertilizer is relatively low.

The production of mustard is in the leaves, therefore the fertilizer given should contain a lot of Nitrogen $(\mathrm{N})$. One of the functions of nitrogen is to improve the plant vegetative part, especially to form leaves chlorophyll, so that physiological processes such as photosynthesis and respiration will work optimally (Surtinah, 2006).

Nitrogen and phosphorus deficiency can affect the number of leaves. The number and area of leaves is one indicator of plant growth and development. Giving goat manure organic fertilizer can increase the availability of nitrogen, phosphorus and other elements needed by plants (Amrullah et al., 2013).

Organic fertilizer can improve soil structure to make it looser so that the root system can develop better and the nutrient absorption process runs more optimally (Rahayu and Tamtomo 2017). Not only accepted by the plant, but the effect of nutrition will also be received by a microbe so that it can support in plant growth (Geisseler and Scow, 2014).

The liquid containing microorganisms (bacteria) that are useful for plants and soil fertility such as Rhizobium sp, azospirillum $\mathrm{sp}$, azotobacter $\mathrm{sp}$, pseudomonas $\mathrm{sp}$, bacillus $\mathrm{sp}$, and phosphate solvent bacteria and are the result of their own production of natural materials around us (local). This natural material is a preferred place as a medium for a living and developing microorganisms that are useful in accelerating the destruction of organic materials (decomposers) or as additional nutrients for plants (Amalia, 2008). It is a preferred place as a medium for the living and developing microorganisms that are useful in accelerating the destruction of organic materials (decomposers) or as additional nutrients for plants (Amalia, 2008).

Mustard plant growth must be supported by the environment around the plant such as temperature and light intensity, which is really important on plant growth. Light is needed for photosynthesis. In addition, $\mathrm{N}$ nutrient deficiency causes stunted plants (Decoteau, 2000).

The results of research by Andrianto (2007) which states that Leri water or rice washing water can stimulate the growth of the roots of Adenium plants. This is because rice washing water contains vitamin B1 which functions to stimulate growth and root metabolism. The benefits of rice (Leri) washing water have also been studied by Yulianingsih (2017), the first washing water of rinse rice has an effect on increasing the number of leaves and height of purple eggplant plants.

\section{CONCLUSION}

Based on the results of the study, it can be concluded that:

1. There is no significant interaction between the concentration of rice washing water and manure doses on the growth and yield of mustard greens.

2. The rice washing water has no significant effect on plant height and the number of leaves of mustard plants.

\section{REFERENCES}

Aisyah S., Hapsoh., Ariani E. 2018. Pengaruh Beberapa Jenis Pupuk Kandang Dan NPK Terhadap Pertumbuhan Dan Hasil Bawang Merah (Allium ascalonicum L.). JOM FAPERTA, 5(1): $1-13$.

Andrianto, H. 2007. Pengaruh Air Cucian Beras pada Adenium. Skripsi. Fakultas Keguruan dan Ilmu Pendidikan. Universitas Muhammadiyah Surakarta. 
Amalia A. 2008. Pembuatan starter/MOL (Mikro Organisme Lokal) oleh Petani. http://organicfield.wordpress.com/. [10 April 2010].

Amitasari. 2016. Pertumbuhan Tanaman Sawi Caisim (Brassica juncea L.) Secara Hidroponik Pada Media Pupuk Organik Cair dari Kotoran Kelinci dan Kotoran Kambing. Publikasi Ilmiah. Universitas Muhammadiyah Surakarta.

Amrullah E. Rastiyanto., Sutirman dan Pullaila A. 2013. Pengaruh Pemberian Pupuk Organik Kotoran Kambing Terhadap Pertumbuhan dan Hasl Tanaman Kailan (Brassica oleraceae. L). Buletin Ikatan, 3(2): 36-40.

Cahyono, B. 2003. Teknik dan Strategi Budidaya Sawi Hijau (Pai-Tsai). Yayasan Pustaka Nusatama, Yogyakarta. Hal 12-62.

Decoteau. D.R. 2000. Vegetative Crop. The Pennsylvania State University, USA.

Geisseler, Daniel, and Kate M Scow.2014. "Long-Term Effects of Mineral Fertilizers on Soil microorganisms-A Review." Soil Biology and Biochemistry. 75: 54-63.

Hairudin, R. 2015. Efektivitas Pupuk Organik Air Cucian Beras terhadap Pertumbuhan Tanaman Sawi (Brassica juncea L.). Jurnal Perbal, 3(3): 79-84.

Handiyanto, S., Hastuti, U.S., dan Prabaningtyas, S. 2013. Kajian Penggunaan Air Cucian Beras Sebagai Bahan Media Pertumbuhan Murni Jamur Tiram Putih (Pleurotusostreatus var.florida). hal 1-9. Seminar Nasional X Pendidikan Biologi FKIP UNS 10(2). Hal 112.

Haryanto, Eko. 2007. Sawi dan Selada. Penebar Swadaya. Jakarta.

Ismaya, N. R. P dan Hamka. 2014. Interval Waktu Pemberian Pupuk Organik Cair Urin Sapi Pada Pertumbuhan dan Produksi Tanaman Kangkung Darat (Ipomoea reptans Poir).J. Agrisistem 10(2): 170-178.

Kii. F.H.A., Jannah H dan Mirawati B. 2018. Pengaruh Pupuk Guano Burung Walet Terhadap Pertumbuhan Tanaman Cabai Rawit (Capsicum frutescens L.). Prosiding Seminar Nasional. Lembaga Penelitian dan Pendidikan (LPP) Mandala, Universitas Muhammadiyah Mataram.

Lestari, Kesi Budi. 2010. Efektivitas Penyiraman Air Leri dan Ekstrak Sari Kedelai Terhadap Pertumbuhan Tanaman Cabai Hibrida (Capsicum annum L). Skripsi. Surakarta : Universitas Muhammadiyah Surakarta.

Putri, W. Lanisia. 2013. Pengaruh Air Cucian Beras pada Media Tanam terhadap produksi Jamur Tiram Putih (Pleurotus ostreatus L.) Skripsi Program Studi Pendidikan Biologi STKIP PGRI Sumbar, Padang.

Rahayu, Sri, and F Tamtomo. 2017. Efektivitas Mikro Organisme Lokal (Mol) Dalam Meningkatkan Kualitas Kompos, Produksi Dan Efisiensi Pemupukan N, P, K Pada Tanaman Ubi Jalar (Ipomoea batatas L.).”Jurnal AGROSAINS, 13(2): 21-29.

Rosmarkam, A dan Nasih, W.Y. 2002. Ilmu Kesuburan Tanah. Kanisius, Yogyakarta. Hal 46.

Sajimin, Y. C., Rahardjo, Nurhayati D., Purwanti. 2005. Potensi Kotoran Kelinci Sebagai Pupuk Organik dan Manfaatnya Pada Tanaman Sayuran. Lokarya Nasional Potensi dan Peluang Pengembangan Usaha Agribisnis Kelinci. Bogor : Balai Penelitian Ternak Bogor. 
Sitompul, S.M dan B. Guritno. 1995. Analisis Pertumbuhan Tanaman. UGM Press. Yogyakarta.

Subandi, M., Nella Purnama Salam, Budy Frasetya, 2015.Pengaruh Berbagai Nilai EC (Electronic Conductivity) terhadap Pertumbuhan dan Hasil Bayam (Amarantus sp.) pada Hidropinik Sistem Rakit Apung. Jurnal Istek, 9(2):136-151.

Supardi, Agus., 2011. Aplikasi Pupuk Cair Hasil Fermentasi Kotoran Padat Kambing Terhadap Pertumbuhan Tanaman Sawi (Brassica juncea L.) Sebagai Pengembangan Materi Mata Kuliah Fisiologi Tumbuhan. Surakarta : Universitas Muhammadiyah Surakarta.

Suparhun S., Anshar M dan Tambing Y. 2015. Pengaruh Pupuk OrganikDan Poc Dari Kotoran Kambing Terhadap Pertumbuhan Tanaman Sawi (Brassica juncea L.). e-J. Agrotekbis, 3(5): 602-611.

Surtinah. 2006. Peranan Plant Catalyst 2006 Dalam Meningkatkan Produksi Sawi (Brassica junceaL.). Jurnal Ilmiah Pertanian, 3(1): 6-10.

Vika, T. Irmansyah,Jonatan Ginting.2018. Respons Pertumbuhan dan Produksi Dua Varietas Kedelai Hitam (Glycine soja L.)Terhadap Aplikasi Pupuk Organik Cair Urin Ternak. Jurnal Agroekoteknologi FP USU, 6(2): 192-199.

Wardiah, Linda dan Rahmatan, H. 2014. Potensi Limbah Air Cucian Beras Sebagai Pupuk Organik Cair pada Pertumbuhan Pakchoy (Brassica rapa L.). Jurnal Biologi Edukasi, 6(1): 34-38.

Wulandari C, Muhartini S, dan Trisnowati S. 2011. Pengaruh Air Cucian Beras Merah dan Beras Putih Terhadap Pertumbuhan dan Hasil Selada (Lactuca sativa L). Skripsi. Fakultas Pertanian. Universitas Gadjah Mada. Yogyakarta.

Yulianingsih R. 2017. Pengaruh Air Cucian Beras Terhadap Pertumbuhan Dan Hasil Terung Ungu (Solanum Melongena L.). PIPER, 24(13): 61-68. 